\title{
Land and identity in South Africa: An immanent moral critique of dominant discourses in the debate on expropriation without compensation
}

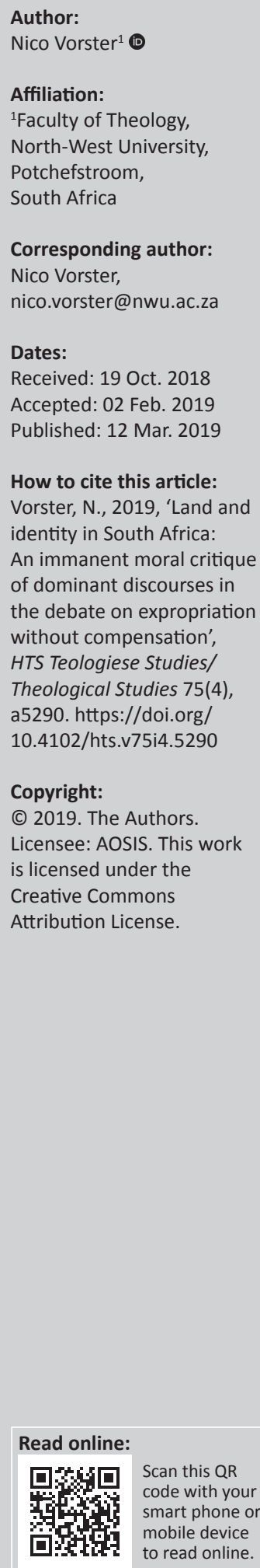

Ownership is an important identity marker. It provides people with a sense of autonomy, rootedness and opportunity. This essay examines the oral submissions of civil organisations to the Joint Constitutional Review Committee (04-07 September 2018) about the issue of land expropriation without compensation. The discussion pays specific attention to the philosophical understandings of land and identity that emerged during the hearings. Three dominant trajectories came into play, namely land as commodity, land as social space and land as spiritual inheritance. Some submissions espoused more than one view, which indicates that the boundaries between the identified paradigms are permeable. However, even those presentations tended to prioritise one approach above the others. Besides identifying the main approaches to land and identity, this essay also provides an immanent critique of their moral assumptions. In contrast to a transcendental approach, an immanent critique asks questions from 'within' and evaluates paradigms in terms of their plausibility, universal applicability, ethical consistency and moral integrity.

\section{Introduction}

Land reform, redistribution and restitution are arguably the most polarising topics in contemporary South African politics. Almost a decade ago, Gibson (2009) described the land question as a 'tinderbox' waiting to ignite. Discord about land reform flared up recently after the governing African National Congress's (ANC) elective conference informed the South African public in December 2017 of their intent to have Section 25 of the Constitution amended to make land expropriation without compensation possible. Concerned that the ANC may hijack the central theme of their political manifesto, the Economic Freedom Fighters (EFF) sponsored a motion in Parliament that proposed a radical change to Section 25, essentially making the state the custodian of all land. Intense lobbying followed and the ANC eventually supported the EFF motion in Parliament, provided that some caveats be added to the proposed amendment of Section 25. These entail that land redistribution should be implemented in a manner that does not endanger agricultural production or food security (Merten 2018:6-7). In the end, Parliament decided to refer the matter to the Joint Constitutional Review Committee to recommend whether the Constitution should be amended to allow for expropriation without compensation, and if so, how this should be done (see Banking Association of South Africa 2018:5).

The Constitutional Review Committee embarked on an extensive consultation process, accepting written submissions and holding land hearings all over the country. The well-attended and often emotionally charged land deliberations in each province were eventually followed up with a hearing in Parliament from 04-07 September 2018 where selected civil society organisations made oral submissions to the Constitutional Review Committee.

During these hearings, some deeply embedded philosophical tensions with respect to land and its link with identity came to the fore. Is land a commodity, a social space, a cultural artefact and a divine inheritance? Can property rights be alienated from individuals or are property rights fundamental to human dignity? Can the state act as a custodian of all land without impairing the dignity of individuals? Does land house sacred spaces that are fundamental to the dignity of faith communities? The questions that arose about land and identity should not surprise us, because the land debate in South Africa inevitably connects groups of people to a specific 'past' (Gibson 2009:127). The hearings clearly illustrated that black experiences are generally pervaded

Note: HTS 75th Anniversary Maake Masango Dedication. 
with a sense of being dispossessed, displaced and alienated from the right to land and ownership; while many white landowners exhibit existential anxiety about the possibility of land grabs and the looming prospect of being disowned and uprooted. The hearings reiterated that we cannot underestimate the importance of ownership in the identity formation of individuals and groups. To most people, ownership is an important identity marker that provides them with a sense of autonomy and rootedness, an opportunity for personal self-realisation, access to the broader economy, bargaining power and social space.

\section{Aim and method}

The aim of this article is to identify the dominant philosophical understandings of land and identity that surfaced during the EWC debate and to present an immanent moral critique of the basic tenets they espoused. To identify and understand the main discourses, I examined a range of written submissions to the Constitutional Review Committee, listened to recordings of oral presentations before the Committee from 04 to 07 September 2018, consulted the High Level Panel Report (2017) and perused academic literature. Three dominant trajectories came to the fore, namely land as a commodity, land as social space and land as spiritual inheritance. Admittedly, not all of the submissions fitted neatly into a category. Some presentations were undergirded by the land both as social space and spiritual inheritance understandings, while various proponents of the commodity approach exhibited sympathy towards social understandings of land.

Conversely, some exponents of the land as social space paradigm raised concerns about economic realities.

Nevertheless, despite the overlaps and general permeable nature of the categories, the named categories adequately reflect the main premises exuded in the EWC debate. Groups who incorporated more than a single land concept into their submissions tended to prioritise one notion as leitmotif, while other concepts were considered either as derivative or of secondary importance.

Besides descriptive analysis, the article provides an immanent moral critique of the strengths and weaknesses of the identified narratives. President Ramaphosa rightly points out that the South African land debate is 'moral' at its core, because it concerns the redress of past discriminative legislation (see Merten 2018:3). The article's choice for an immanent rather than transcendent moral critique of the land discourses in the EWC debate is governed by the public nature of the debate and the ensuing need to engage distinctive social imaginaries in their own terms. By 'immanent' I mean that the various approaches are evaluated 'from within' in terms of their plausibility, logical consistency, the presuppositions and values that orient their outlook, their moral coherency and universal applicability when it comes to justice values. A transcendent critique, in contrast, evaluates a particular discourse 'from without' in terms of an alternative set of values. Detractors may argue that the distinction between immanent and transcendent moral critique is superficial, because immanent critiques are inescapably based on the philosophical, religious or ethical presuppositions of some worldview or ethical system. In a sense, so it is argued, we always talk from the 'outside'. This is of course true. My intention is not to claim that immanent critiques are 'neutral' or to assert that transcendent critiques are invalid. Instead, I argue that an immanent approach has particular value when groups are attempting to reach consensus on a specific topic of national importance. Transcendent critiques, in contrast, have limited value in such dialogues because participants who use paradigmspecific language tend to speak 'past' one another, especially when their paradigms are totally incommensurable.

Immanent approaches, in contrast, force us to engage with an ethics system on its own terms, to listen to the argument, to draw from its strengths and to point out inconsistencies and anomalies in a line of reasoning rather than evaluating it purely in terms of another worldview.

\section{Land as commodity}

The land as commodity paradigm ${ }^{1}$ emerged predominantly from submissions made by role players from the banking, civil rights and commercial agriculture sectors. Groups such as Agri-South Africa, Agri-Business, Grain SA, the South African Institute of Race Relations and the Banking Association of South Africa set forth a notion of land as a measurable and definable entity that is exchangeable and tradable. ${ }^{2}$ These groups generally approached the viability of land reform from a market-oriented logic and posited profit-making, economic growth, job creation and food security as important outcomes of responsible land reform (see Agri SA 2018; Banking Association of South Africa 2018:3). They also tended to be negative about self-sustaining small-scale farming and communal ownership, because such models are considered as unprofitable and unproductive (see Agri SA 2018:24). Moreover, they maintained that the state should not act as custodian of all land because this would open the door to corruption and power abuse (Agri SA 2018:14; South African Institute for Race Relations 2018:14).

In line with their understanding of land as an exchangeable commodity, this approach emphasises the right to private ownership as a fundamental feature of a free and open society. Private property rights were presented as an important precondition for human dignity. The South African Institute for Race Relations, for example, argued that EWC would compromise the rule of law and endanger the foundational

1.Historically speaking, the ANC's approach to land reform has also been strongly informed by the notion of land as commodity. Kepe and Hall (2018:132-133) note that the State's latest land redistribution strategy, entitled the Proactive land Acquisition Strategy (PLAS), is framed in terms of commercial viability, productivity and land utilisation. Quite surprisingly it stipulates that land occupants can be forced to relocate if they don't make productive use of land. In the debate on forced to relocate if they don't make productive use of land. In the debate on expropriation without compensation, the ANC also maintained that land conducive to investment and economic growth (see Merten 2018:6-7).

2.Asked by an EFF member of the Constitutional Review Committee what he understand by land as commodity, Grain SA's presenter, Mr Jannie de Villiers, understand by land as commodity, Grain SA's presenter, Mr Jannie de Villiers, is exchangeable and transactionable (04 September, You Tube). 
values of the South African Constitution, specifically human dignity, equality and freedom. The Banking Association, in a similar vein, stated that prosperity and property rights are 'inextricably linked', as property rights are 'the basis of exchange' and the 'extension of ownership to capital goods' (2018:4). Agri SA (2018:14) claimed that individual property rights are internationally recognised for good reason - they protect individuals against government 'excesses' and power abuse. The Helen Suzman Foundation and the South African Institute for Race Relations also accentuated the importance of property rights and posited that a blanket allowance for expropriation without compensation would amount to a contravention of the basic human rights principles of a constitutional state. After complaining that political groups are attempting to racialise the land debate, the South African Institute for Race Relations warned that 'doctrines of collective guilt' have no place 'in a democracy founded on individual rights' (2018:17).

When it comes to poverty alleviation, proponents of the commodity paradigm emphasised the importance of free markets, economic growth and investment as the fundamental drivers of wealth creation. They argued that EWC could exacerbate poverty in South Africa by causing falling property prices, hindering new investments in agriculture and destabilising the pricing mechanisms of markets (Agri SA 2018:19; Banking Association 2018:4-6; South African Institute of Race Relations 2018:33). The Banking Association claimed that the poor, in comparison to the wealthy, tend to spend a larger percentage of their income on agricultural produce. A 'stagnant' agriculture sector may inflate food prizes and could 'impoverish' the poor rather than the rich (2018:6). The association also warned that EWC could create great losses in the banking sector:

Widespread EWC has the potential to create systemic risk for the banking sector, as loan agreements concluded with a bank do not necessarily consider a scenario in which property seizure results in the forcible change of ownership at below market value. If a loan is defaulted upon due to EWC or expropriation occurs at below market value, it is unclear how the lender will be able to recover the losses incurred on the loans granted. (2018:9)

Agri SA (2018:19) similarly stated that EWC would lead to an investment freeze in agriculture, capital outflows, credit down rates, currency depreciation, inflation, an increase in government debt spending, lower tax revenues from agriculture and general contagion to the rest of the economy.

While the need for land reform and deracialising commercial farming is acknowledged by the land as commodity paradigm, proponents of this paradigm generally do not regard land reform as a quickfix for rural poverty (see Cousins \& Scoones 2010:51). The inherent logic of the approach is to agitate for fewer and larger production units that increase viability and feasibility (see Aliber \& Cousins 2015:143). Instead of aggressive land redistribution, it advocates the creation of a group of viable commercial black farmers who can contribute to the larger agrarian economy (see Cousins \& Scoones 2010:500; South African Institute of Race Relations 2018:34). They also stress the importance of security of tenure to enable property occupiers to have access to finance (see Agri SA 2018:6; Banking Association 2018:14; South African Institute of Race Relations 2018:35).

The land as commodity paradigm indeed presents important moral arguments that should not be taken lightly. Firstly, it makes the moral claim that land is a financial asset and a source of income for property owners. The state, therefore, has the obligation to compensate persons who are deprived of property (through expropriation) for losses incurred. Arbitrary deprivations of land amount to a form of unacceptable coercion because property is taken without the consent of the owner. The proprietor is harmed, both emotionally and physically (in terms of livelihood), to a degree that endangers his or her fundamental dignity.

Secondly, the commodity approach's emphasis on food security and land utilisation is an important moral consideration. The EWC debate generally focused on rapid land acquisition, but seemed to underestimate the importance of land utilisation (Vumelana Advisory Fund 2018:19). Access to a consistent supply of nutritional food is not only the most basic precondition for a dignified existence but also paramount to peaceful social cohesion. Food shortages can turn a country into a warzone in a very short period of time.

Events in Zimbabwe and Venezuela illustrate how easily a country can slide into a food crisis when a land reform process destabilises the commercial farming sector. South Africa is without a doubt deeply vulnerable when it comes to food security. Regular droughts, changing weather patterns, volatile markets, the falling numbers of commercial farmers, rising population figures and the high percentage of people in the former homelands who live on land holdings but do not engage in farming are contributing factors (see O'Laughlin et al. 2013:4). Alarmingly, the percentage of arable land not 'cultivated' in the previous 'homelands' is increasing because of insufficient access to capital to buy seed, implements and adequate fencing to protect crops from livestock (O'Laughlin et al. 2013:10). Rather than engaging in capital intensive enterprises, most inhabitants of the former 'homelands' rely heavily on social grants and off-farming productivities for survival (O'Laughlin et al. 2013:13). These factors have implications for the reliability of the South African food supply chain.

Despite the strengths of the commodity approach, some scholars have rightly raised concerns about the moral compass of an approach so strongly informed by neo-classical economics. Cousins and Scoones (2010:31-32) describe the commodity approach as 'narrow, technocratic economism' that does not take the political and social dimensions of land reform into account adequately. Aliber and Cousins (2015:142) also note that the deregulation and liberalisation of the agricultural sector immediately after the demise of apartheid 'facilitated' higher concentrations of land ownership rather than 'opening up space' for small farmers. 
The question is whether the land as commodity approach's emphasis on market-related land reform does not downplay the unequal distribution of property rights in the agricultural sector specifically. The Helen Suzman Foundation rightly observed during the hearings that 'wealth is massively skewed against the black portion of the population in favour of other racial groups, especially the white portion'. Addressing this imbalance on an incremental basis 'through the normal workings of the economy' will take generations (2018:7). Neo-classical economics also tend to commercialise all spheres of life, even spheres such as health and education that should be focused on service delivery rather than profit. Along with commercialisation comes economic competition, and in competitive environments, there are winners and losers. In normal societies, competition and free markets may drive efficiency and creativity, but in a highly unequal society such as South Africa where groups of people were historically subjected to discriminatory legislation, it may entrench patterns of exclusion. Previously disadvantaged communities simply do not have the resources to compete on equal terms in an intricate and capital intensive industry such as agriculture.

As far as the moral integrity of commodity approach is concerned, we may ask: is the emphasis on commercialised farming not perhaps a front to protect vested power interests and to keep marginalised groups from the land? If agricultural efficiency is seen as the yardstick for land redistribution, few members of previously disadvantaged groups will qualify for land ownership. In reality, the commodity approach seems so fixated on the values of maximum profit, maximum efficiency and competitiveness that it can hardly be attuned to the rights of the property-less and dispossessed. When land is purely seen as a source of wealth, a tradable commodity, it could become a temptation and a curse, a location of greedy power conflicts that hinder the fair distribution of social goods. While land utilisation and food security are important considerations in the land debate, it cannot be the only yardstick for successful land reform. In fact, commercial farming currently makes up a small percentage of the South African GDP. One may argue that small-holding farming could alleviate extreme poverty by at least sustaining villages or groups of families.

\section{Land as social space}

South Africans who attach social meanings to land generally tend to consider land as a space of rootedness, a locus of life and a place of history-making where identities are formed. Some traditional Southern African societies, for instance, bury the umbilical cord of a newborn baby near the location of the birth to root that person in a place of origin, which is shared with the ancestors (Beinart, Delius \& Hay 2017:loc 76).

Masenya and Ramantswana (2015:102) also note that some indigenous South African ethnic communities identify themselves by referring to the land on which they lived. An area occupied by a clan would be called after the clan's name, while the family name, correspondingly, would refer to the land as place of origin.

They claim that many traditional African groups view land as an inalienable 'inheritance' that should be passed on from one generation to the other (2015:103). In fact, for most South Africans, access to land is not primarily about finding a livelihood, but about reconnecting to historical roots. Seventy percent of black respondents in Gibson's survey (2009:40) indicated that they regard the symbolic value of land and the issue of dignity as more important than monetary considerations.

Land as a space that provides historical meaning and cultural identity was a recurrent theme during the Constitutional Review Committee hearings. The Apostolic Faith Mission of South Africa (2018:5), for example, described land as a space directly related to the issue of 'who I am, where I come from, where I belong'. The Orania Movement (2018) held that land is not, first of all, a commodity, but a locus of culture making. They described expropriation without compensation as a means to misrecognise Afrikaner culture and as part of a larger effort to destroy Afrikaner culture. The Vumelana Advisory Fund stressed that segregation (1910-1948) and apartheid (1948-1990) robbed the dispossessed of their dignity. For these people, land has become a 'symbol of dispossession' that has affected many dimensions of their lives (2018:8).

Whereas some organisations depicted land reform as a means to reconnect to historical roots, other groups were more concerned about the power dynamics that still determine ownership patterns. Pan-Africanist and decolonisation discourse perceive land as the apex of colonial conquest and as a locus of resistance, while existing patterns of land ownership are considered as a continuation of colonialist oppression (see Kepe \& Hall 2018:130-131). They therefore call for stringent processes of redress and some even propagate the complete de-commodification of land through nationalisation. Black Land First (BLF), for instance, stated that land is not a commodity, but belongs to the people. The land of black people was, according to BLF, stolen by white people, and it should therefore be returned to the black people. According to them, Section 25 ought to be removed and replaced by a clause explicitly stating that all land belong to black people and has been stolen by white people (2018). The Land and Accountability Research Centre (LARC) also expressed concern about prevailing power relations, but argued that traditional leaders and the state actually entrench apartheid forms of land custodianship by holding land 'on behalf of the people' and binding rural black people to group identities and territorial borders $(2018: 15,20)$.

Another feature of the land as social and cultural space trajectory was a concern with the dehumanising effects of landlessness and extreme poverty. Organisations closely involved in social development projects generally took the plight of the poor as premise. Phulisani NPC (2018:2) 
described the land debate as a 'discussion about the deeprooted inequalities which characterize our society and the persistent marginalization of the majority of South Africans'. The Rural Development Agency (2018) noted that land reform concerns the restoration of people's dignity, giving them an opportunity to secure a livelihood, allowing them to live near their working place and addressing unequal ownership patterns. LARC (2018:3) emphasised that land reforms should benefit vulnerable communities and that they should be used to drive development, while the Foundation of Human Rights argued that Section 25(1) of the Constitution introduces bias towards property owners and does not strike an adequate balance between the rights of owners and the vast majority of dispossessed black people (2018:8). The Foundation emphasised the right to ownership of labour tenants and farm workers who lived for many years on land without owning part of it (2018:9). They went as far as stating that land currently utilised by labour tenants should be expropriated without compensation from current owners. Compensation 'will amount to over accumulation, as labor tenants have already paid for this portion of land through free labor provided over many decades' (2018:10).

The Foundation also reminded the Committee of the need to address the land rights of women and the poor in rural and peri-urban areas (2018:10).

The moral strength of the land as social and cultural space trajectory lies in its understanding that land ownership influences the well-being of whole communities and affects generations of people. Places have historical meaning for people, are the arenas of identity formations and provide inter-generational continuity and meaning to peoples' lives (Bruegemann 2002:loc 336). Land usage is never a purely individual concern insulated from the interests or well-being of wider society or of future generations. With ownership comes duties to the wider community. Long after we have gone, our decisions still affect land ownership patterns, the ecology and economic production. The social approach reminds us of the inconvenient truth that landowners cannot ignore the history of land grabs in South Africa. Present generations have a moral duty to confront the burden of history to establish a more stable and equal society.

Having said this, the arguments of some extremist exponents of the land as social space paradigm are morally problematic. The first issue concerns the 'origin' of land rights. The collectivist approaches of the National House of Traditional Leaders, BLF and political groupings such as the EFF tend to undermine individual autonomy and destroy any concrete sense of personal ownership by vesting land rights in communities rather than persons. Whenever identity is linked exclusively to belonging to a certain tribe or group, and land rights are vested in the group, it opens up the possibility of traditional leaders and the state to entitle themselves to act as custodians of land on behalf of individual persons. But when individual autonomy is sacrificed at the altar of group interests, and land rights are derived from a chief or state, collective forms of power abuse inevitably emerge. LARC rightly pointed out during the public hearing that 'the move away from transferring property rights to black owners' and the tendency to vest land rights in the state, traditional councils and trusts who act as custodians of land by leasing land, have actually perpetuated the land dispossession of poor black people (LARC 2018:2). Kepe and Hall (2018) make a similar observation:

Land reform is increasingly taking place through strategic partnership and other institutional forms that prevent black people from getting and controlling land themselves. Instead the State is the 'willing buyer' which is buying up land at market price and retaining ownership, allocating use rights or leaseholds, often to white-owned companies or multi-nationals, while signing up farm workers as 'beneficiaries'. (p. 133)

The HLP report also expressed unease about the establishment of communal property associations (CPAs) that aggregate groups of people into property owners of specific tracts of land. The report notes that the CPAs have 'locked people into imposed group identities against whom it is difficult to assert specific rights or enforce accountability' (2017:302). The problem is exacerbated by the lack of existing legislation to protect the tenure security of vulnerable people in the former homelands (HLP 2017:266).

The moral argument here is that power abuse should be avoided by distributing centres of power. The recognition of individual property rights is the best way to protect the individual against collective power abuse. Property rights, encapsulated in a title deed and visible in a piece of soil, are touchable and concrete rights, whereas some other rights in life seem to have mere symbolic, or at best, indirect practical value.

When land rights are not circumscribed in land deeds, but vested in the state or traditional councils, confusion tends to arise on the actual rights of those who live on the land. Undefined lease tenures open the door for abuse and corruption and aggravate the insecurity that tenants experience (Helen Suzman Foundation 2018:19). They also discourage inhabitants from spending money on property infrastructure and developing commercially viable businesses on the land (see Helen Suzman Foundation 2018:13).

A second moral issue concerns the link between moral accountability and personal agency. Proponents of the blanket expropriation without compensation of all whiteowned land seem to argue that Person A can be held to account for the actions of Person B because he or she has benefitted indirectly from Person B's actions. The Vumelana Advisory Fund (2018) encapsulates the popular perception that exists among some as follows:

There is a sense of continuing injustice in the idea that those who profited from the land from which the original occupants were removed without compensation should keep their profits and be compensated for the land they are now required to give up. (p. 8)

The abovementioned notion, however, simplifies the moral complexity of the problem. During the apartheid and 
segregation eras, the state engaged in land expropriation without compensation and then sold the land to individual buyers. In other words, while private owners may have attained land at discounted prices, land was rarely distributed for free. Moreover, in the vast majority of cases in South Africa, land was sold by the original owners to new proprietors. Citing the study of Aliber (2015), the Vumelana Advisory Fund (2018:10) indicated that 63\% of privately owned commercial land changed hands in the market in the period between 1994 and 2008. We can safely assume that this percentage has risen considerably in the past decade.

So, we are confronted with the moral question: can people be held morally accountable for actions they did not commit themselves? I argue that when we separate moral accountability from personal agency, we enter dangerous domain by opening the door to arbitrary actions and a 'guilty by association' stereotyping of groups. At the same time, it is clear that systemic and structural causes of inequality cannot be left unresolved and that redistribution of land is vitally important for future stability in South Africa. Thus, we are left with a conflict of moral duties: on the one hand, land redistribution is required to stabilise and normalise South African society; conversely, we want to avoid a situation where redress obliterates the crucial bond between moral accountability and personal agency.

The South African Constitution provides probably the best and most moral solution when it stipulates that land owners affected by land restitution ought to be compensated in a just and equitable way for losses incurred. Agri SA (2018:14) also alludes to the moral principle of equal treatment in the bearing of public burdens. If one member of society has to bear an excessive burden for the redress of past injustices committed by past generations, society as a whole in the form of the state has a duty to compensate that person fairly for losses incurred (see Agri SA 2018:14). What just and equitable compensation entails ought to be determined on a case-by-case basis and should be subject to judicial review in accordance with the principle of rule of law.

Those who support EWC claim that expropriation without compensation will speed up land reform processes. However, this rather pragmatic view is not morally tenable, because practical considerations cannot override basic principles of fairness, nor is it a proven fact that expropriation without compensation will streamline processes. In truth, as the Vumelana Advisory Fund (2018:13) indicates, expropriation leads to protracted court cases. Most restitution cases have been 'resolved through financial compensation', and no evidence exists that compensation leads to high land prices or that land prices have been a key issue in tenure reforms.

A third moral issue that arises with regard to the land as social space paradigm is that stories about rootedness differ and that various groups make different historical claims to the same pieces of land. The harsh reality is that South African history has been characterised by a range of land grabs, not only by white colonialists but also between black tribes who entered into war with each other. A question that arises is: how far back can we go to address historical injustice and how practical is restorative justice procedures in a fast-changing landscape? One view increasingly promoted by some claimants, specifically Khoi groups in the Western Cape, is that land restitution should be about indigenisation, that is, land should be returned to indigenous groups (Beinart et al. 2017:loc 1696). In response, I would say that the 1913 cut-off date for land restitution claims is fair because a unitary state was introduced in 1910. Using earlier dates as reference for redress will make land reform overly complicated. We simply no longer live in a tribal and pre-modern agrarian society. The principle at stake in land reform is not whether to return society to some kind of ideal original state but to provide restitution to communities directly harmed by segregation and apartheid laws and to put into effect a fairer distribution of goods that will stabilise and normalise ownership patterns in South Africa.

\section{Land as spiritual inheritance}

Spiritual approaches view land as a space and place where God, people and soil interact (see Verhoef \& Rathbone 2015:167). Several oral submissions to the Joint Committee of Constitutional Review (04-06 September 2018) suggested that land is a divine endowment, while others described land as an ancestral inheritance. Spiritual understandings of land and identity, of course, have a long history of South African discourse. Nineteenth century Afrikaner dispositions to landownership were, among other things, characterised by a literalist understanding of the 'Promised Land' and conquest narratives in the Old Testament. Vorster (2006:686) indicates that many Voortrekkers identified closely with ancient Israel and considered themselves as a people elected by God to drive away heathen nations from God's Promised Land. Christian British colonialists, on the other hand, considered colonialisation as part of a missionary endeavour to bring the light of the Gospel to the 'pagans' of the world (Vorster 2006:686). Although these ideas are no longer common among white South Africans, most Christian white farmers still consider land as an inheritance from God and themselves as stewards who received a calling from God to cultivate land.

Traditional black communities in South Africa also tend to assign a deeply religious meaning to land. Adherents of African traditional religions generally believe in an 'enchanted' universe where the spiritual and material realm, ancestors, spirits and living beings are all part of one interactive reality. Land is regarded as an inheritance of God or the gods who assign land to a specific tribe or ethnic group (see Masenya \& Ramatswana 2015:103). Ancestors are seen by some as guardians and protectors of surviving families and by others as malevolent forces that can exercise feardriven rule over the lives of people ( $\mathrm{Nel} \mathrm{2018:8).} \mathrm{The} \mathrm{bond}$ between group and land is viewed as sacred and as overruling all other considerations. 
The spiritual approach to land revealed itself most clearly in presentations by churches and traditional community forums. The Every Nation Churches (2018) stated that God owns land and delegates stewardship to the people. Land must be shared among those who work the land and should not be concentrated in the hands of the few, whether it be the state or individuals. They rejected the notion of the state acting as custodian of all land, because this would amount to ascribing a divine status to the state. The church group called for a land reform process marked by justice, love and fairness, and reconciliation between current owners and the dispossessed. Although they emphasised the importance of land redistribution, they also underscored that land cannot lie dormant. The Parliamentary Liaison Office of the Southern African Catholic Bishops Conference (2018) observed that land has spiritual and religious associations for many groups in South Africa and is closely intertwined with people's perceptions of identity and heritage.

According to them, land should not be treated purely as a commodity. The Creator, after all, intends land to be used by all people to the benefit of all people. Drawing on the Catholic notion of the universal destination of goods, they posit that there can be no absolute right to land and that a state may be entitled to deprive owners of ownership for the sake of the common good and restitutive justice. Owners are entitled to compensation, unless there are extraordinary reasons not to compensate. However, they warn that although expropriation without compensation may be ethically justifiable in certain cases, it could cause more harm than good.

The National African Farmers Union (2018) described land as a divine gift 'free of charge' to the people of South Africa, who are all created in the image of God. Land is therefore priceless. The union called for the nationalisation of land, the abolishment of private ownership and a fair reorganisation of the ownership structures in South Africa through a system where citizens lease property from the state. The National House of Traditional Leaders (2018b) defined land as an ancestral inheritance to traditional communities that must be returned to the communities. They argued that communal land has been adulterated by colonialists who dispossessed African communities and tribes, reconfigured land ownership and undermined traditional authority. According to this group, traditional leaders are custodians of the values of their communities and should be recognised as such. Expropriation without compensation mechanisms should be used to transfer land to dispossessed communities, while their traditional councils should be allowed to decide on how the land would be utilised. At the same time, land currently owned by traditional leaders should be left alone.

The House demanded that the Constitution be changed comprehensibly as it is a continuation of the Western governance system. The Limpopo Communal Institute (2018), in a similar vein, claimed that the African ancestors lost land through the Land Natives Act of 1913. The dignity of people can only be restored by giving the land back to its rightful owners. Government is the rightful owner of land and should redistribute land through title deeds.

The aforementioned examples of this paradigm illustrate both the diversity of worldviews in South African society and the complicated nature of the land debate. Non-religious detractors would probably argue that supernatural worldviews have no place in public debates, because metaphysical understandings of reality can neither be proven nor falsified. Public discourse, so the argument goes, ought to be governed by sound reason and established facts. The reality, however, is that religious views are foundational to the worldviews of many South Africans and can therefore not be taken out of the equation. Attempts to exclude all religious reasoning from the public debate would not only aggravate the sense of marginalisation that many groups, especially traditional communities, experience, but they also rest on the problematic assumption that secular worldviews are superior to transcendent imaginaries, because they are supposedly based on hard facts devoid of philosophical assumptions. However, in the age of post-Enlightenment, we can no longer accept the existence of a neutral and objective human reason, nor a naked public sphere guided by the light of human reason alone. All worldviews utilise philosophical presuppositions as point of orientation. A better approach to public debate, in my view, would be to allow participants to be open and honest about their philosophical premises and to utilise the resources of their traditions, while seeking 'as much agreement as possible' with other traditions (Wolterstorff 2012:9).

This principle goes two ways. It not only allows religious groups to speak in the public domain in their own language according to their traditions but also entails that spiritual or religious groups cannot impose their views on other social imaginaries simply because they claim to speak with a divine mandate. Public discourse is about persuasion and all views expressed are open to critical scrutiny. The acceptability of theological, religious and spiritual understandings of land should be measured in terms of their plausibility, ethical consistency and integrity, universal applicability and compatibility with basic principles of justice. For example, most mainline Christian traditions share the notion of land as a divine gift to be equitably shared by all human beings who are created in the image of God and who are called to act as stewards of God's creation. This view may not be empirically verifiable, but it is rationally plausible. Moreover, it is ethically useful because it does not absolutise human ownership, but views ownership as a secondary right derived from God, who is the absolute owner of all things. It emphasises that all human beings are created equally in the image of God and share in a divine calling to cultivate and preserve God's creation. It is universally applicable from a justice point of view because it locates rights in the individual person, albeit as gifts of God. The narrative is also well suited to challenge the concentration of land in the hands of the few, to express the dignity of labour, to oppose ecological degradation and to counteract poverty (see Butler \& Philpott 2005:216; Wright 1990:117). 
However, as was evident from the public hearings, religious approaches to land can also be abused to solidify vested interests. When groups claim land as divine promise or ancestral inheritance, their ownership cannot be disputed nor can the land be traded or expropriated for legitimate public purposes because the land is proclaimed as sacred. But such religious discourses are almost never politically innocent (Bruegemann 2002:loc 40). The logic is clearly devised to claim land, to absolutise ownership and to assert that some humans are nobler than others because they are divinely chosen. Such exclusionary ideologies are morally highly problematic, because they compromise basic justice values such as fairness, even-handed treatment and the equal dignity of all people.

Traditional African 'Promised Land' narratives may claim to resist colonial occupation and oppression, but they inadvertently espouse the same kind of 'Promised Land' ideology that colonialists utilised to justify land grabs, with disastrous consequences. In fact, land reform experiences have indicated that tribal and ancestral notions of land are highly susceptible to exploitation by traditional authorities. The High Level Panel Report (2017), the book of Beinart et al. (2017) and the study of Kepe and Hall (2018) all express concern that the land reform process is currently being captured by chiefs and traditional leaders who endanger the tenure security of vulnerable people. According to the High Level Panel Report (HLP 2017:203), 'the problem is especially acute' in former homeland areas and in areas administered by the Ingonyama Trust where traditional leaders and officials often claim to have the sole right to sign agreements with 'investors in respect of communal land'.

\section{Conclusion}

An analysis of the oral and written presentations submitted to the Joint Constitutional Review Committee indicates that the debate was dominated by three narratives on land and identity. The land as commodity approach emphasised the measurable, exchangeable and tradable nature of land; the sanctity of private property rights as a precondition for prosperity; the need for compensation when owners incur losses because of expropriation; and the importance of land utilisation and food security for the dignified existence of a population. The narrative's emphasis on food security, land utilisation and individual property rights is important from a moral point of view, but we should ask whether the commodity approach is sufficiently attuned to the rights of the poor and property-less? Does the neo-classical economical emphasis on free trade, maximum efficiency and maximum profit not enhance the concentration of wealth in the hands of the few? Is the economic argument devised by this approach not perhaps a disguised attempt to protect vested power interests?

The land as social space trajectory considers land as a place of history making, identity formation and social rootedness. Due regard is given to the systemic impact of ownership patterns on the well-being of generations. The approach shows a deep concern for the rights of the landless and emphasises the dehumanising effects of poverty. Some strands of this trajectory maintain that the South African land issue illustrates the perpetuation of colonial ownership patterns. For them, land has become a symbol of dispossession and social alienation in South Africa. They classify land as a locus of social resistance and therefore call for stringent redress and land redistribution. Despite its moral strengths, some strands within the approach raise serious moral concerns. By vesting land rights in the state or community rather than the individual person, it gives significant power to authorities and opens the door to corrupt practices in land redistribution. Various land experts have shown that vesting land rights in traditional authorities or the state encourages new forms of black land dispossession. Another troubling moral issue relates to the manner in which the paradigm severs the link between moral accountability and personal agency to justify collective forms of historical redress. A theoretical disconnect between moral accountability and personal agency could result in certain members of society being stereotyped as 'guilty' because of their historical lineage and as deserving of arbitrary justice. Lastly, some groups racialise the land debate by calling for the indigenisation of land. However, land reform cannot be aimed at returning South Africa to an 'ideal' original situation, but must rather ensure a fair distribution of social goods in a plural modern state.

The spiritual approach views land as a divine gift and space where God, people and land interact. African traditional groups tend to view the universe as 'enchanted' and maintain that land is an inheritance from the ancestors. The sacral bond between land and people cannot be alienated. Dispossessed land should therefore be returned to its rightful owners. Traditional African groups generally tend to support EWC as a means to restore ownership patterns. Christian groups, conversely, hold that God is the ultimate owner of land and that he appoints human beings created in his image as stewards of his earth. God's earth belong to all people and social goods should therefore be fairly distributed. They supported redress, but seemed reluctant to endorse EWC. This article argues that religions' opinions should be allowed in the public sphere, but that religious imaginaries cannot escape critical scrutiny simply because they base their views on theological notions. Although religious views may be plausible and ethically useful, their political innocence should not be assumed, as 'divine promise' and 'ancestral inheritance' narratives are often used to solidify entrenched interests.

\section{Acknowledgements Competing interests}

The author declares that he has no financial or personal relationship(s) that may have inappropriately influenced him in writing this article.

\section{References}

Agri SA, 2018, Submission on land expropriation without compensation, viewed 11 September 2018, from http://www.forestry.co.za/uploads/File/Industry $\% 20$ News/2018/May 
Aliber, M., 2015, 'Unravelling the "willing buyer, willing seller" question', in B. Cousins \& C. Walker (eds.), Land divided, land restored: Land Reform in South Africa for the 21st century, pp. 145-160, Jacana Media, Auckland Park.

Aliber, M. \& Cousins, B., 2015, 'Livelihoods after land reform in South Africa', Journa of Agrarian Change 13(1), 140-165. https://doi.org/10.1111/joac.12012

Apostolic Faith Mission of South Africa, 2018, AFM of SA presentation on land expropriation without compensation, viewed 17 September 2018, from http:// afm-ags.org/wp-content/uploads/2018/06/

Banking Association of South Africa, 2018, Public submission to the constitutional review committee, viewed 01 October 2018, from http://www.banking.org.za/docs/

Beinart, W., Delius, P. \& Hay, M., 2017, Rights to land. A guide to tenure upgrading and restitution in South Africa, Jacanda Media, Johannesburg.

Black Land First, 2018, Oral submission before parliament joint committee of constitutional review, viewed 05 September 2018, from https://www.youtube. com/user/ParliamentofRSA

Bruegemann, W., 2002, The land. Place as gift, promise and challenge in biblical faith, 7 th edn., Fortress Press, Minneapolis, MN.

Butler, M. \& Philpott, G., 2005, 'Land in South Africa: Gift for all or commodity for a few?', Studies in World Christianity 11(2), 215-235. https://doi.org/10.3366/ swc.2005.11.2.215

Cousins, B. \& Scoones, I., 2010, 'Contested paradigms of "viability" in redistributive land reform: perspectives from southern Africa', The Journal of Peasant Studies 37(1), 31-66. https://doi.org/10.1080/03066150903498739

Every Nation Churches, 2018, Oral submission to parliament joint committee of constitutional review, viewed 05 September 2018, from https://www.youtube. com/user/ParliamentofRSA

Foundation of Human Rights, 2018, Submission to the constitutional review committee, viewed 18 September 2018, from http://www.fhr.org.za/files/5815/3665/9559/ FHR_Submission_to_the_Constitutional_Review_Committee.pdf

Gibson, J.L., 2009, Overcoming historical injustices. Land reconciliation in South Africa, Cambridge University Press, New York.

Grain SA, 2018, Oral submission to parliament joint committee of constitutional review, viewed 05 September 2018, from https://www.youtube.com/user/ParliamentofRSA

Helen Suzman Foundation, 2018, Submission to the joint constitutional review committee of parliament on the review of section 25 of the constitution (property clause, viewed 01 October 2018, http://pmg-assets.s3-website-eu-west-1.amazonaws.com/ 180629hsf.pdf

High Level Panel Report, 2017, Report of the high level panel on the assessment of key legislation and the acceleration of fundamental change, viewed 05 Septembe 2018, from https://www.parliament.gov.za/storage/app/media/Pages/2017/ october/High_Level_Panel/HLP_Report/HLP_report.pdf

Kepe, T. \& Hall, R., 2018, 'Land redistribution in South Africa: Towards decolonisation or recolonisation?', Politikon 45(1), 128-137. https://doi.org/10.1080/02589346. 2018.1418218

Land and Accountability Research Centre, 2018, Submission to the joint constitutiona review committee, viewed 01 October 2018, from http://www.larc.uct.ac.za/sites/

Limpopo Communal Institute, 2018, Oral submission before parliament join committee of constitutional review, viewed 05 September 2018, from https:// www.youtube.com/user/ParliamentofRSA

Masenya, M. \& Ramatswana, H., 2015, 'Lupfumo lu Mavuni (Wealth is in the land): In search of the promised land (cf. Exod 3-4) in the post-colonial, post-apartheid South Africa', Journal of Theology for Southern Africa 151, 96-116.
Merten, M., 2018, Parliament: Historic land expropriation agreement reached amid South Africa's changing politics, viewed 28 February 2018, from https:// amid South Africa's changing politics, view
dailymaverick.co.za/section/south-africa

National African Farmers Union, 2018, Oral submission before parliament joint committee of constitutional review, viewed 05 September 2018, from https:// www.youtube.com/user/ParliamentofRSA

National House of Traditional Leaders, 2018a, Oral submission to parliament joint committee of constitutional review, viewed 05 September 2018, from https:// www.youtube.com/user/ParliamentofRSA

National House of Traditional Leaders, 2018b, Oral submission to the joint constitutional review committee, viewed 06 September 2018, from https://www. youtube.com/user/ParliamentofRSA

Nel, M., 2018, 'African Pentecostalism and its view of rulers, authorities, evil powers, cosmic powers on the continent, and spiritual forces in the heavenly realm', Unpublished paper delivered at North-West University Conference on Theological narratives in Africa. Rulers, authorities, cosmic powers on the continent, spiritual forces in the heavenly realm and the Church, North-West University, Potchefstroom, 31 August.

O'Laughlin, B., Bernstein, H., Cousins, B. \& Peters, E.E., 2013, 'Introduction: Agrarian change, rural poverty and land reform in South Africa since 1994', Journal of Agrarian Change 13(1), 1-15. https://doi.org/10.1111/joac.12010

Orania Movement, 2018, Oral submission before parliament joint committee of constitutional review, viewed 05 September 2018, from https://www.youtube. com/user/ParliamentofRSA

Phulisani, N.P.C., 2018, Submission to the constitutional review committee on expropriation without compensation within a future tenure regime for South Africa, viewed 20 September 2018, from http://pmg-assets.s3-website-eu-west-1. amazonaws.com/180629Phuhlisani-Submission.pdf

Rural Development Agency, 2018, Oral submission to parliament joint committee of constitutional review, viewed 04 September 2018, from https://www.youtube. com/user/ParliamentofRSA

South African Bishops Conference, 2018, Submission to the Joint Constitutional Review Committee on Section 25 of the Constitution and the need to expropriate land without compensation, viewed 17 October 2018, from https://www.cplo.org. za/summary-of-the-sacbc-land-submssion/

South African Institute for Race Relations, 2018, Submission to the joint constitutional review committee regarding its review of section 25 and other sections where necessary to make it possible for the state to expropriate land in the public interest
without compensation, viewed 11 September 2018, from https://irr.org.za/ without compensation, viewed 11 September 2018, from https://irr.org.za/
reports/submissions-on-proposed-legislation/irr-full-submission-to-jointconstitutional-review-committee-14-june-2018.pdf

Verhoef, A. \& Rathbone, M., 2015, 'A theologically informed ontology of land in the context of South African land redistribution', Journal of Theology for Southern Africa 152, 156-170.

Vorster, J.M., 2006, 'The ethics of land restitution', Journal of Religious Ethics 34(4), 685-707. https://doi.org/10.1111/j.1467-9795.2006.00290.x

Vumelana Advisory Fund, 2018, Submission to the joint constitutional review committee on the review of section 25 of the Constitution to make it possible for the state to expropriate land in the public interest without compensation, viewed 20 September 2018, from www.vumelana.org.za/wpcontent/uploads/2018/06/00 Vumelana submission_14_Jun_2018_vFINAL.pdf

Wolterstorff, N., 2012, The mighty and the almighty, Cambridge University Press, Cambridge.

Wright, C.J.H., 1990, God's people in God's land. Family, land and property in the Old Testament, Eerdmans, Grand Rapids, MI. 